\title{
De Templo de Salomón a luciente relicario. Visión y ekphrasis de la Catedral de Jaén
}

\author{
Carmen GonZÁLEZ-RomÁN \\ Universidad de Málaga \\ Departamento de Historia del Arte \\ romancg@uma.es
}

Recibido: 3-12-2013

Aceptado: 16-10-2014

\section{RESUMEN}

La imagen de la Catedral de Jaén que nos ha transmitido la literatura artística enriquece la visión e interpretación del Templo a lo largo de los siglos. La más singular de todas las fuentes, exponente del imaginario barroco, es la que lo relaciona con el Templo de Jerusalén. La ekphrasis arquitectónica de la Catedral de Jaén se inaugura en el siglo XVII con la Descripción Panegírica de Juan Núñez Sotomayor, quien sustenta los detalles de la estructura y pormenores del edificio en precisas alusiones a la magna obra salomónica. Lejos de agotarse en la sugerente retórica barroca, el repertorio de imágenes del templo mayor giennense continúa y se acrecenta en singulares ejercicios de ekphrasis hasta la actual centuria.

Palabras clave: Catedral de Jaén, Templo de Salomón, ekphrasis, Juan Núñez Sotomayor, literatura artística, metáforas edilicias, imaginario barroco.

\section{From Solomon's temple to shining reliquary. Vision and ekphrasis of the Cathedral of Jaén}

\begin{abstract}
The image of the Cathedral of Jaén transmitted to us by artistic literature has enriched the vision and interpretation of the Temple over the centuries. The most unique of all sources, exponent of Baroque imagery, is the one that relates it to the Temple of Jerusalem. The architectural ekphrasis of the Cathedral of Jaén commences in the $17^{\text {th }}$ century with the panegyric description by Juan Núñez Sotomayor, who explains the details of the structure and the building by means of precise allusions to the great solomonic work. Far from reaching its climax with the suggestive Baroque rhetoric, the repertoire of images of the major Jaen's temple continues and heightens in unique exercises of ekphrasis until the present century.
\end{abstract}

Key words: Cathedral of Jaén, Solomon's temple, ekphrasis, Juan Núñez Sotomayor, artistic literature, architectural metaphors, Baroque imagery. 
Decía Fernando Chueca Goitia, en un artículo publicado un año antes de su muerte, que el paisaje circundante de Jaén le recordaba a Grecia. ${ }^{1}$ Constituía esta imagen, sin lugar a dudas, una sugerente referencia a lo escarpado de la topografía giennense pero también, de algún modo, el paisaje sobre el que se eleva la ciudad de Jaén y su Catedral, podría evocar la imagen de la acrópolis ateniense, entendida esta como sinécdoque del paisaje helénico [fig.1]. El arquitecto madrileño, que había declarado en más de una ocasión su entusiasmo por la ciudad de Jaén y estudiado con rigor la Catedral, contribuía de algún modo con esta visión a culminar una metáfora centenaria que asociaba el Templo Mayor con una fortaleza divina. En efecto, la idea de recinto amurallado o fortaleza militar constituye una imagen relacionada con la Catedral, un edificio que detentaba la salvaguarda de la ciudad en lo que a funciones espirituales se refiere. Pero esta es sólo una de las imágenes, entre otras, que del templo mayor nos ofrece la literatura. ${ }^{2}$

Las descripciones sobre la Catedral de Jaén también han reparado durante siglos en la proporcionalidad que emana del conjunto, no faltando en dichos relatos la valoración y el parangón con la arquitectura de la Antigüedad. En todo momento se subraya su magnificencia, una grandiosidad que reside, como ya señaló Pedro Galera: "en la belleza de la armonía proporcional entre el todo y cada una de sus partes, de acuerdo a la más genuina belleza clasicista dada por León Battista Alberti; una belleza que conmueve por su racionalidad". ${ }^{3}$

Pero la visión de esta Catedral que nos ha transmitido la literatura artística, lejos de agotarse en estas referencias, se enriquece con todo un conjunto de metáforas alusivas al esplendor y la riqueza del edificio; así como a alegorías que simbólicamente representan el espacio celeste, la más representativa de las cuales, y exponente del imaginario barroco, es la que relaciona la construcción catedralicia con el Templo de Jerusalén.

Al tratar de las imágenes de la catedral de Jaén hablaré, por tanto, de visión y écfrasis, porque la écfrasis como género literario es una descripción que trata de hacer presente el objeto artístico y, en este sentido, constituye un caso particular y extremo de la figuratividad del lenguaje, al presentarse como la descripción de una imagen tan efectiva que induce la imaginación del lector a recomponer en la mente el objeto o acción descrita. ${ }^{4}$ Aunque la écfrasis, como descripción vívida del objeto artístico,

1 CHUECA GOITIA, Fernando: "Jaén y Andrés de Vandelvira", Boletín del Instituto de Estudios Giennenses, $\mathrm{n}^{\circ} 186$ (2003), pp. 83-91.

2 Este trabajo no pretende llevar a cabo una relación exhaustiva de todas las alusiones a la Catedral de Jaén contenidas en la literatura, para ello véase el riguroso estudio de VALLADARES REGUERO, Aurelio: “Testimonios literarios sobre la Catedral de Jaén”, Elucidario, n ${ }^{\circ} 5$ (2008), pp. 137-158. Nuestro propósito es recuperar las imágenes proyectadas por el edificio en el imaginario colectivo a lo largo de los siglos, desde su consagración, hasta los inicios de la actual centuria, para ello trataremos de desvelar las metáforas sobre las que se han construido dichas imágenes.

3 GALERA, Pedro: La Catedral de Jaén. Madrid, Lunwerg, 2009, p.13.

4 Ekphrasis es el vocablo griego que en la retórica antigua designaba cualquier tipo de descripción vívida, aquella que tiene la capacidad de poner el objeto descrito delante de los ojos del receptor, es decir, lo que los latinos llamaron evidentia. Hermógenes (siglos II-III) añadía que hay écfrasis "de personajes, de hechos, de circunstancias, de lugares, de épocas, y de otros muchos objetos". En el sentido más estricto de la palabra, se trata de una composición poética que "da voz a un objeto artístico mudo" o que ofrece "una descripción retórica 
no deja de constituir una quimera, la imposibilidad de la écfrasis de hacernos "ver" el objeto, se supera con la imaginación o la metáfora, aspecto que W. J. T. Mitchell denomina "esperanza ecfrástica". ${ }^{5}$

El recorrido por la literatura en torno a la Catedral de Jaén que aquí propongo me lleva a hablar, por tanto, de imágenes, entendido este término como el conjunto de representaciones o asociaciones simbólicas del edificio, que trascienden lo meramente material, que entroncan con el imaginario de una época, y que favorecen, en definitiva, la interpretación y valoración del objeto artístico.

La descripción arquitectónica como capítulo específico dentro de la literatura ecfrástica hunde sus raíces en la época helenística y romana, pero alcanza su plenitud en tiempos de Justiniano con las descripciones de Santa Sofía en Constantinopla realizadas por Procopio y Pablo Silenciario. ${ }^{6}$ En aquella ocasión, como en algunas de las que vamos a referir en relación al Templo Mayor giennense, además de un relato pormenorizado de lo material y mensurable, hallamos una interpretación simbólica del edificio y sus partes. ${ }^{7}$ Cada descripción viene a representar además, lo que Murray Krieger denomina "momento detenido", ${ }_{8}^{8}$ momento en que las palabras pueden describir o encarnar estados estáticos o espaciales, algo que sucede cuando el lenguaje poético se vuelve icónico, y las figuras utópicas de la imagen y de su presentación textual constituyen ventanas transparentes hacia la realidad.

de una obra de arte", vid. HAGSTRUM, Jean H.: The Sister Arts: The Tradition of Literary Pictorialism and English Poetry from Dryden to Gray. Chicago, University of Chicago Press, 1958, cfr. MITCHELL, W. J. T.: Teoría de la imagen. Ensayos sobre representación verbal y visual. Madrid, Akal, 2009, p. 139. Una aplicación más general, que es la que en este trabajo seguimos, incluye todo conjunto de descripciones que tengan el objetivo de situar un lugar, una situación o una imagen artística ante el ojo mental del espectador. Para una aproximación teórica a este género véase CALLE, Román de la: El espejo de la Ekphrasis. Más acá de la imagen. Más allá del texto -La crítica de arte como paideia-. Lanzarote, Fundación César Manrique, 2005. Un recorrido por la bibliografía en torno a la écfrasis la encontramos en PINEDA, Victoria: "La invención de la écfrasis" en Homenaje a la profesora Carmen Pérez Romero. Universidad de Extremadura, Facultad de Filosofía y Letras, 2000, pp. 251-262.

5 Vid. MITCHELL, W. J. T.: Teoría de la imagen, op. cit.

6 Para la retórica ecfrástica en Bizancio resultan de gran utilidad, MACRIDES, Ruth y MAGDALINO, Paul: "The architecture of Ekphrasis: Construction and Context of Paul the Silentiaty's Ekphrasis os Hagia Sofia", Byzantine and Modern Greek Studies, no 12 (1988), pp. 47-83. LIZ, James y WEBB Ruth: "To Understend Ultiate Things and enter Secret Places: Ekphrasis and Art in Byzantium", Art History, 14, no 1 (March 1991), pp. 1-7. Estas y otras interesantes referencias bibliográficas en PEREDA ESPESO, Felipe: "Leer en la Catedral: La experiencia de la arquitectura en 1549" en GONZÁLVEZ, R. y PEREDA, F.: La Catedral de Toledo 1549 según el Dr. Blas Ortiz Descripcion Graphica y Elegantissima de la S. Iglesia de Toledo. Toledo, Antonio Pareja, 1999.

7 Véase en el contexto de la écfrasis arquitectónica de la Edad Moderna, la descripción de la Catedral de Málaga realizada por Gaspar de Tovar en sus dos ediciones: Pintura y Breve recopilación de la obra de la Santa Iglesia Mayor de Málaga. Hecha por el licenciado Gaspar de Tovar racionero en ella, impreso en Antequera por Claudio Bolán, 1603, y la posterior edición ampliada: Pintura y Breve Recopilación de la insigne obra de la Santa Iglesia de Málaga. Compuesto por el Licenciado Gaspar de Tovar, Racionero en ella. En canciones, impreso en Málaga por Juan René en 1607, vid. GONZÁLEZ-ROMÁN, Carmen y SÁNCHEZ LÓPEZ, Juan Antonio, Arquitecturas literarias, metáforas edificadas. Gaspar de Tovar y la imagen poética de la catedral de Málaga. Estudio introductorio al libro: Pintura y breve recopilación de la insigne obra de la Santa Iglesia de Málaga (1607). Fundación Málaga y R.A.B.A. San Telmo, Málaga, 2007, pp. 17-108.

8 KRIEGER, Murray: Ekphrasis: The illusion of the Natural Sign. Baltimore, Johns Hopkins University Press, 1992. 


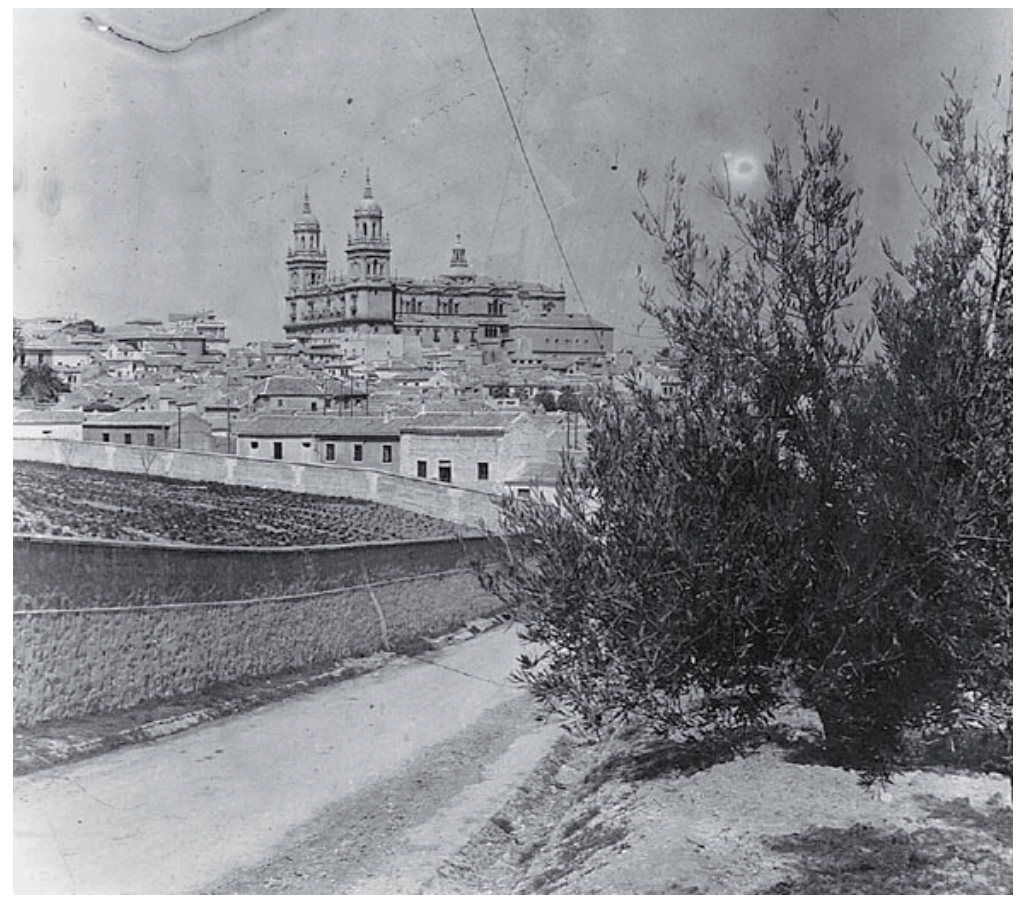

Fig. 1. Vista de la Catedral de Jaén (fotografía de 1862. Códice. Revista de Investigación Histórica y Archivística).

\section{Fortaleza divina y émula del templo de Jerusalén}

La écfrasis arquitectónica de la Catedral de Jaén se inaugura en el siglo XVII con la Descripción Panegírica de Juan Núñez Sotomayor. ${ }^{9}$ El relato, no exento de un

9 NÚÑEZ SOTOMAYOR, Juan: Descripción panegírica de las insignes fiestas que la S.I. Catedral de Iaen celebró en la translación del SS. Sacramento a su nuevo y sumptuoso Templo, por el mes de octubre del año de $1660 \ldots$ En Málaga lo imprimió Mateo Lopez Hidalgo, Impressor de la Santa Iglesia Catedral. Año de 1661. Este ejemplar no aparece recogido en la Bibliografía de Arquitectura, Ingeniería y Urbanismo en España (1498-1880), dirigida por Antonio Bonet Correa y publicada por Turner Libros en 1980; sin embargo, se halla citada en el Diccionario filológico de literatura española. Siglo XVII, vol 1, dirigido por Pablo Jauralde Pou ( $1^{\text {a }}$ edición, Madrid, Castalia, 2010), así como en la ficha correspondiente al proyecto de literatura española PHEBO. Poesía Hispánica en el Bajo Barroco, http://phebo.es/en/registro/descripci\%C3\%B3npaneg $\% \mathrm{C} 3 \% \mathrm{ADrica}$-de-las-insignes-fiestas-que-la-s-iglesia-catedral-de-ja $\% \mathrm{C} 3 \% \mathrm{~A} 9 \mathrm{n}$-celebr $\% \mathrm{C} 3 \% \mathrm{~B} 3$-en (Consultado el 14-10-2014), en donde se referencia su inclusión en los siguientes repertorios bibliográficos: Salvá, I, no 1332; Gallardo, II, no 3249; Simón Díaz, "Primer índice...XVII", p. 154. La ficha realizada por PHEBO indica solamente el ejemplar conservado en la Biblioteca Nacional de España (BNE 2/7347), existen otros ejemplares, como el del fondo antiguo de la Universidad de Sevilla (sig. 204/42), así como el de la Biblioteca del Hospital Real de Granada, consultable en Red en la Biblioteca de Andalucía (ANT-XVII-131). El hecho de que la obra aparezca referenciada en repertorios sobre poesía barroca pone en evidencia la necesidad de revisar la literatura artística que hasta el momento se ha considerado desde la disciplina de la historia del arte, y para ello sería muy conveniente la colaboración de equipos interdisciplinares integrados por 
notable simbolismo político y religioso, recoge la historia eclesiástica de Jaén y nos ofrece la visión de una ciudad-templo en el contexto de una Monarquía Sacra. La descripción se sitúa, en este sentido, en la línea de las grandes narraciones históricas de marcado acento encomiástico herederas de la epidixis conmemorativa. Pero, a diferencia de otras narraciones históricas o corográficas sobre el Reino de Jaén, numerosas en el siglo XVII, en las que se cede a la tentación de la erudición histórica, y se dedican amplios pasajes a la fundación, tradiciones litúrgicas, vidas de santos, reliquias, etc., ${ }^{10}$ Núñez Sotomayor opta por la transmisión verbal de sugestivas imágenes que recrean el contexto festivo, tanto en su dimensión material como espiritual y simbólica, desvelándonos un imaginario que entronca con la cultura literaria y visual de la época.

La imagen de la excelsa construcción catedralicia compuesta por el poeta malagueño a lo largo del Discurso I se fundamenta en el rigor en la relación de proporciones y medidas; en el parangón con la Antigüedad; y en las metáforas alusivas simbólicamente al espacio celeste. La relación de trazas y dimensiones del edificio que dan inicio a la descripción del Templo reflejan un denodado afán de precisión o cientificidad. En este sentido, el discurso de Sotomayor constituye una prolongación de la écfrasis arquitectónica que, a partir del Renacimiento, es partícipe y heredera del nuevo espíritu erudito latente en la tratadística arquitectónica iniciada por Alberti, particularmente en lo que concierne a la precisión en la medida de las partes que componen el edificio. Junto a la exactitud del dato, las "obligadas" alusiones a la Antigüedad, época objeto y modelo de toda ponderación. Así, para valorar la euritmia de la soberbia máquina, Sotomayor no remite al arquitecto florentino, pero sí acude a la autoridad de Vitruvio:

Haze todo una trabazón tan conforme, y bien concertada, que a su vista rindieran vassallage sin oposición los celebrados aciertos del doctissimo Vitrubio. ${ }^{11}$

historiadores del arte y filólogos, vid. GONZÁLEZ-ROMÁN, Carmen: "Del totum revolutum al pernicioso rigor disciplinar. Reflexiones en torno a las fronteras de la literatura artística", en RODRÍGUEZ, Nuria y TAÍN, Miguel (eds.): Teoría y literatura artística en España. Revisión historiográfica y estudios contemporáneos. Madrid, R.A.B.A. San Fernando (en prensa).

10 Véase, para el caso particular del Reino y Obispado de Jaén en el Siglo de Oro, la más importante de todas: XIMENA JURADO, Martín de: Catálogo de los obispos de las iglesias catedrales y anales eclesiásticos de este obispado (Madrid, 1652), Ed. Facsímil, Granada, 1991. Otras obras pertenecientes a la misma centuria y citadas, la mayoría, por Ximena Jurado son: RUS PUERTA, Francisco: Historia eclesiástica del Reyno y Obispado de Jaén... Jaén, por Francisco Pérez de Castilla, 1634. Del mismo autor, Segunda Parte de la historia eclesiástica de este Reino y Obispado con adiciones a la primera. Y la Corographía antiguas y moderna del mismo Reino y Obispado. JIMÉNEZ PATÓN, Bartolomé: Historia de la antigua y continuada nobleza de Jaén (Jaén, 1616). Del mismo autor, Historia eclasiástica del Reino y obispado de Jaén (Jaén, 1634). VÍLCHEZ, Francisco de: Santos y santuarios del obispado de Jaén y Baeza (Madrid, 1653). TERRONES DE ROBRES, Antonio, Vida, martirio, traslación y milagros de S. Euphrasio, obispo y patrón de Andújar. Origen, antigüedad y excelencias de esta ciudad, privilegios de que goza y varones insignes en santidad, letras y armas que ha tenido. Granada, en la Imprenta Real por Francisco Sánchez, 1657. LÓPEZ PINTO, Gregorio: Historia apologética de la muy antiquísima ciudad de Castulo, sus prósperas acciones y adeversos fines, los santos mártires y obispos que se hallan haberlo sido de aquella ciudad. Sobre los libros de antigüedades véase también RALLO GRUSS, Asunción: Los libros de Antigüedades en el Siglo de Oro. Universidad de Málaga, 2002, p. 194.

11 Ibidem, Discurso I, p. 12. 
Tampoco elude el poeta otro de los lugares recurrentes en las écfrasis arquitectónicas de la Edad Moderna, la equiparación a las maravillas de la Antigüedad:

...cuyos primores en la arquitectura, cuya perspectiva en la distribución de sus ventanas, cuya belleza y acierto aún en la parte menor de toda su compostura desvanecen las repetidas voces que han perpetuado el tiempo y la fama, aplaudiendo aquellos siete milagros del arte, que celebró la antigüedad por maravillas. ${ }^{12}$

Una de las imágenes más sugestivas del templo giennense es aquella en la que Sotomayor lo describe como un alcázar o atalaya. La rotundidad con que emergía, y aún destaca, el volumen de la cabecera sobre el contexto urbano generaba la visión de una fortaleza, que, como alcázar divino, se elevaba hasta el cielo, y así viene descrita por el poeta malagueño en el Discurso I. Esta "catedral-fortaleza" era considerada en el ideario barroco una representación del espacio celeste, como se colige igualmente del segundo assvmpto de la justa poética celebrada con motivo de la consagración del Templo mayor, el cual debía versar sobre la idea de que la Catedral de Jaén sube al cielo y el cielo baja a ella. Esta es la imagen que reproducen los sonetos que compitieron en esta modalidad del certamen:

Oy contra el natural sube hasta el cielo/ el Alcaçar Divino que ha ilustrado/ uno y otro Santissimo Prelado ${ }^{13}$

La metáfora del "alcázar divino" posee indudables connotaciones bíblicas. Este edificio, que aparece continuamente citado en los Salmos, es símbolo inequívoco de Dios y guarda relación con la idea repetida en el Antiguo Testamento de Yahvé como roca. En una oración de acción de gracias, David alaba al Señor como " $m i$ roca, $m i$ alcázar" (2 Sal. 22,2); en otras ocasiones leemos: "Sé mi roca de refugio, alcázar que me salve, porque tú eres mi peña y mi alcázar" (Sal. 31., 3s); "Refugio mío, alcázar mío, Dios mío, confio en ti" (Sal 91., 1s). ${ }^{14}$

La Catedral de Jaén es, en consecuencia, presentada por Sotomayor como eminente baluarte espiritual, destinado a salvaguardar la Fe en toda la diócesis:

...parece que con su empinada extremidad señorea las regiones, hasta chocar con la diáfana escultura de ese celestial edificio...de atalaya sirve a todos los espacios del contorno. ${ }^{15}$

12 Ibidem, p. 23.

13 Ibidem, p. 423.

14 Sobre las claves retóricas e ideológicas del relato de Núñez Sotomayor presentes tanto en las metáforas del edificio, como en los sermones, altares y demás elementos festivos que acompañaron la consagración del templo giennense, véase el riguroso y erudito estudio de GARCÍA BERNAL, José Jaime: "El templo y el imaginario festivo del Barroco. A propósito de la descripción panegírica de Núñez Sotomayor", Studia historica. Historia moderna $\mathrm{n}^{\circ} 30$ (2008), pp. 273-318. En el Antiguo Testamento la idea de Yaveh como roca la encontramos en los siguiente pasajes:1S 2,2; 2S 22,3.32.47; 23,3; Sal 18,3.32.47; Sal 19,15; Sal 28,1; Sal 31,3.4; Sal 71,3; Sal 92,16; Sal 94,24; Is 26,4; Is 44,8. Agradezco al Dr. Carlos Pena Buján las referencias que me ha facilitado.

15 NÚÑEZ SOTOMAYOR, Juan: op. cit., Discurso I, p. 21. 
Descrita de este modo, la catedral constituye una potente imagen que compite con el otro edificio emblemático de la ciudad, el castillo, entablándose una dialéctica entre la imagen de ambas "fortalezas" en el paisaje urbano de Jaén. Considerado desde esta perspectiva, la catedral como "alcázar divino" remite a la imagen del escudo del Templo Mayor en el que los altos muros de una fortaleza alcanzan las nubes sobre las que aparece representada la Virgen sedente con el niño en brazos y pisando el dragón [fig. 2]. ${ }^{16}$ Así, la Catedral, como bastión de la Fe, se construye simbólicamente en la poesía de Sotomayor como un trasunto de la fortaleza divina, articulándose la ciudad terrena a imagen de la ciudad celeste.

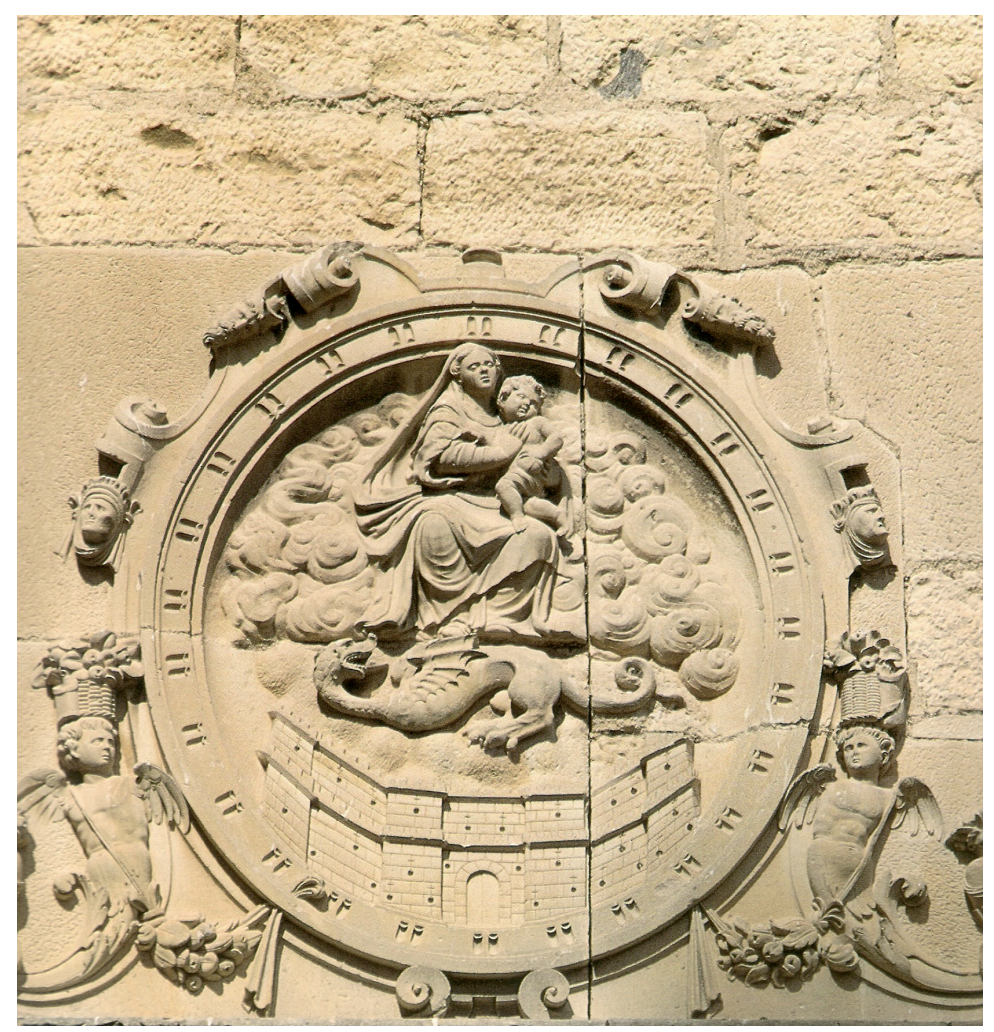

Fig. 2. Escudo de la Catedral de Jaén situado sobre la ventana de la antesacristía (ca. 1560).

La Descripción de Núñez Sotomayor no escapa a la sugestión hierosolimitana al presentarnos la catedral como una evocación del célebre santuario salomónico, una imagen de gran valor simbólico y a la vez, acorde con la configuración real del edi-

16 Sobre la presencia y significado del dragón en el escudo de la Catedral de Jaén véase GALERA ANDREU, Pedro: "Corografía de ciudades con forma de animal. La ciudad de Jaén y la figura del dragón" en El Sueño de Eneas. Imágenes utópicas de la ciudad, Víctor Mínguez, Inmaculada Rodríguez y Vicent Zuriaga (eds.). Universitat Jaume I. Biblioteca Valenciana. Generalitat Valenciana, Castelló, 2009, pp. 45-64. 
ficio. ${ }^{17}$ Frente a la imagen artística del "Templum Salomonis" como metonimia de la ciudad de Jerusalén que desde la Edad Media vino dada por fantásticas descripciones del edificio como estructura centralizada, y que cuenta con evidentes reminiscencias en la cabecera de la Catedral de Granada, ${ }^{18}$ la Catedral de Jaén se ajusta al tipo de planta rectangular, más en consonancia con la auténtica fisonomía de la Jerusalén terrenal con que la arqueología y los comentaristas a partir del siglo XVI, ilustraron el Templo de Salomón [fig. 3].

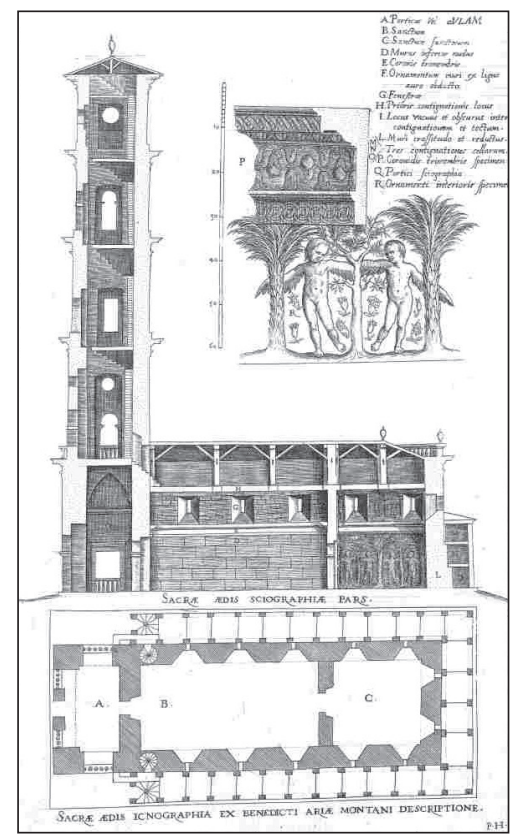

Fig. 3. Benito Arias Montano. Exemplar sive de Sacris Fabricis Liber. Antverpiae, Christophorus Plantinus, 1572.

17 La imagen del templo como objeto simbólico en su relación con la "Jerusalén celeste" ha sido analizada por GARCÍA MAHÍQUES, Rafael: "La Jerusalén celeste como símbolo de la Iglesia. Su configuración durante el primer milenio" en El Sueño de Eneas. Imágenes utópicas de la ciudad, op. cit., pp. 19-44. También se han ocupado del tema de la Jerusalén celestial, en este sentido del templo, otros investigadores como RODRÍGUEZ G. DE CEBALLOS, Alfonso: "El simbolismo de la Jerusalén Celeste: constante ambiental del templo cristiano", Arte sacro y Concilio Vaticano II. León, Junta Nacional de Arte Sacro, 1965; SEBASTIÁN LÓPEZ, Santiago: Mensaje Simbólico del arte Medieval. Arquitectura, Iconografía, Liturgia. Madrid, Encuentro, 1994. Sobre la tipología de planta de la Catedral de Jaén véase también la interpretación de F. J. López Morales, para quien el modelo catedralicio de planta rectangular o de salón adoptado por Vandelvira se adapta a las circunstancias de los nuevos tiempos de reconquista en la península Ibérica y de las tierras americanas, un modelo que "recuerda el inicio de la cristianización, es decir, la adaptación de la basílica como inspiración y recinto para el nuevo espacio cristiano y el nacimiento de la primitiva catedral", cfr. GALERA, Pedro: La Catedral de Jaén. Madrid, Lunwerg, 2009, p. 9.

18 Sobre la referencia al Templo de Salomón en la cabecera de la Catedral de Granada, de acuerdo con la tradición medieval de representación centralizada de la ciudad santa en estampas y pinturas, véase GALERA, Pedro: "La cabecera de la Catedral de Granada y la imagen del "Templo de Jerusalén", Cuadernos de Arte de la Universidad de Granada $\mathrm{n}^{\circ}$ XXIII (1992), pp. 107-117. 
La estructura y detalles del edificio descrito por Núñez Sotomayor se sustenta en precisas alusiones a la magna obra salomónica, así sucede, por ejemplo, cuando describe el pavimento ajedrezado de mármol blanco de Filabres y jaspe negro con algunas venas blancas, tan terso, bruñido y transparente que como en el Templo de Salomón, sirve de clarissimo y taraceado espejo a la distante y elevada belleza de su cielo. ${ }^{19}$ Otra interesante mención la encontramos en la descripción del sagrario de madera dorada el cual, a juicio del poeta, por única emulación se pudiera imaginar del trono de Salomón en su lucimiento. ${ }^{20}$

En el contexto festivo de la consagración del templo giennense, el símil con el Templo hierosolimitano se hace explícito en la justa poética, donde dicho edificio se incardina con la Jerusalén celestial de la profecía apocalíptica. El primer assvmpto ofertado a concurso consistía en escribir una canción, de seis estancias de trece versos cada una, donde se comparase la Catedral de Jaén con el Templo de Salomón. El parangón con el célebre Templo de Jerusalén se establece en estas composiciones a partir de una serie de correspondencias entre ambos edificios, particularmente en lo que se refiere a sus promotores y a la similitud en los actos festivos organizados en cada caso. De entrada, la traslación del Santísimo Sacramento a su nuevo y suntuoso templo de Jaén es equiparada a la acción llevada a cabo por David al transportar el Arca a Jerusalén:

Assi lo hizo David quando trasladó el Arca del Testamento de casa de Obededon a la ciudad Santa de Jerusalén, donde como Principe religiosamente generoso, construyó Altares que fuesen al Arca decentes... busco músicos que en dulces vozes y bien templados instrumentos repitiessen los versos de un cántico que compuso... O Santa Iglesia de Jaen! En tu translación executas lo mismo q David aconseja. Para agradecer a dios la gloria de ver acabada esta Iglesia, tus ciudadanos juntas. Para que te miren agradecida, los estraños convocas... ${ }^{21}$

Las alusiones a la magnificencia de las fiestas y demás ostentosos pormenores remiten también al bíblico templo:

Luego que acabó su templo Salomón lo dedicó a Dios, y con solemnísimas fiestas celebró aquella única maravilla de los siglos. El concurso de su celebridad fue incomprensible y el de la que Jaén consagró a la dedicación de su Templo no se puede reducir a número. ${ }^{22}$

A la hora de enaltecer las dos personalidades que posibilitaron la culminación del templo giennense, el cardenal D. Baltasar de Moscoso y Sandoval, Arzobispo de Toledo y antes Obispo de Jaén, y D. Fernando de Andrade y Castro Obispo de Jaén, se hace corresponder ambos prelados con símbolos preclaros del templo salomónico,

19 NÚÑEZ SOTOMAYOR, Juan: op. cit. Discurso I, pp. 6-7.

20 Ibidem, p. 19.

21 Ibidem, pp. 398-399.

22 Ibidem, p. 34. 
como son los querubines que custodiaban el Arca en el templo de Jerusalén, ${ }^{23}$ las dos columnas que flanqueaban la entrada al templo, ${ }^{24} \mathrm{o}$ bien, se les atribuye el papel de nuevo Salomón. ${ }^{25}$

Zelaban alli el Arca misteriosa/dos Cherubines cuyas plumas bellas/ heredaron al Sol los resplandores./ Zelan aquí la Vrna mas preciosa/ Baltasar y Fernando a cuyas huellas/ debe el jaspe y el mármol sus honores. ${ }^{26}$

...son los dos polos donde estriba toda la firmeza de este templo; las dos columnas son en cuyas cumbres (como en las de Salomón) rinden las azucenas cándidos triunfos que aclaman sus victorias. ${ }^{27}$

Andrade y Castro, Salomon sagrado/ sabio, prudente, generoso y pio,/ nuevo gran Machabeo, cuyo brio/ oy aclama en encenios regozijos/Jaen Palestra de la Fé; y sus hijos... ${ }^{28}$

Si nos atenemos a las palabras del biógrafo del cardenal Moscoso y Sandoval, fray Antonio de Jesús María, la idea de aquel era fabricar a Dios un insigne Templo, ${ }^{29}$ con lo cual la acción llevada a cabo por el prelado se corresponde también con la desempeñada por el sabio rey en Jerusalén. Esta actividad asignada al obispo giennense entronca con la tradición que convirtió a Dios en arquitecto, recogida en parte en la Biblia, siendo el pasaje más claro respecto a los términos en los que Dios se dirigió a Salomón aquel que se recoge en Sabiduría: "tú me encargaste construir un templo en tu monte santo y un altar en la ciudad en donde habitas, a imitación de la tienda santa que preparaste desde el principio". ${ }^{30}$

23 Exodo 25, 17-22. En este pasaje se recoge la descripción del Arca de la Alianza y el mandato de Yaveh: "Harás dos querubines de oro batido a los dos extremos del propiciatorio, uno al uno, otro al otro lado de él. Los dos querubines estarán a los dos extremos..."

24 El libro tercero de los Reyes y las profecías de Ezequiel habían sido en el siglo XVI la principal fuente de información de las exégesis sobre el Templo de Salomón, la más célebre de las cuales fue la de los jesuitas Prado y Villapando. El texto de Villalpando elaborado a partir del comentario al profeta Ezequiel, en los capítulos 40 al 44, incluía la traza y arquitectura del templo y describía las columnas que eran el fundamento del orden de la arquitectura del edificio. Vid. GARCÍA BERNAL, José Jaime: op. cit. En relación a las columnas como sinécdoque del Templo, véase RAMÍREZ DOMÍNGUEZ, Juan Antonio: Construcciones ilusorias. Arquitecturas descritas, arquitecturas pintadas. Madrid, Alianza, 1983, pp. 130-143., y la aportación del mismo autor en el insustituible Dios, Arquitecto. Juan Bautista Villalpando y el Templo de Salomón. Madrid, Siruela, 1991, pp. 17-24. Una reciente revisión del tema y actualización bibliográfica en PENA BUJÁN, Carlos: La Arquitectura civil recta y obliqua de Juan Caramuel en el contexto de la Teoría de la Arquitectura del siglo XVII. Tesis Doctoral. Universidad de Santiago de Compostela, 2007, pp. 135140. En lo que concierne a la bibliografía internacional más reciente, merecen mencionarse, en relación el templo hirosolimitano, BALFOUR, Alan: Solomon's Temple: Myth, Conflict and Faith. Wiley-Blackwell, 2012; HAMBLIN, William, J. y SEELY, David: Solomon's temple: Mith and History. London, Thames \& Hudson, 2007.

25 RAMÍREZ DOMÍNGUEZ, Juan Antonio (coord.): Dios, Arquitecto... op. cit.

26 NÚÑEZ SOTOMAYOR, Juan, op. cit., Discurso VII, p. 410.

27 Ibidem, p. 28.

28 Ibidem, p. 414.

29 GALERA, Pedro: La catedral de Jaén... op. cit., p. 77.

$30 \mathrm{Sb}$ 9,8. Véase "Del cielo a la tierra: Arquitectura y Teología" en PENA BUJAN, Carlos: La Arquitectura civil op. cit., pp. 75-110. 
Las correspondencias salomónicas expresadas en la literatura tienen su plasmación iconográfica en el programa de la portada norte del crucero de la Catedral giennense [fig. 4]. ${ }^{31}$ Allí, sobre la escultura de Ezequiel se encuentra el escudo de don Baltasar de Moscoso y, simétricamente ubicadas al otro lado de la portada, sendas esculturas de Salomón y el escudo de la Catedral. En esta ocasión, la metáfora del "alcázar divino", plasmada en el escudo del Templo, se inserta de modo evidente en el discurso salomónico, una asociación que será teorizada de modo contundente pocos años más tarde por Juan Caramuel de Lobkowitz. En efecto, Caramuel afirmará que Dios habría sido el diseñador del edificio más perfecto que había existido sobre la Tierra, el templo de Jerusalén que, a decir del cisterciense, era "Templo, Palacio, Castillo y Alcaçar" y, por tanto, "habiendo de tener tantas riquezas, havia de edificarle manera que las pudiesse defender" 32 . Caramuel sostuvo la idea del Templo de Salomón como arquitectura militar hasta el punto de llegar a decir que sólo con conocerlo bastaría "para gobernar la Regla y Compás en todo genero de fortificaciones"33.

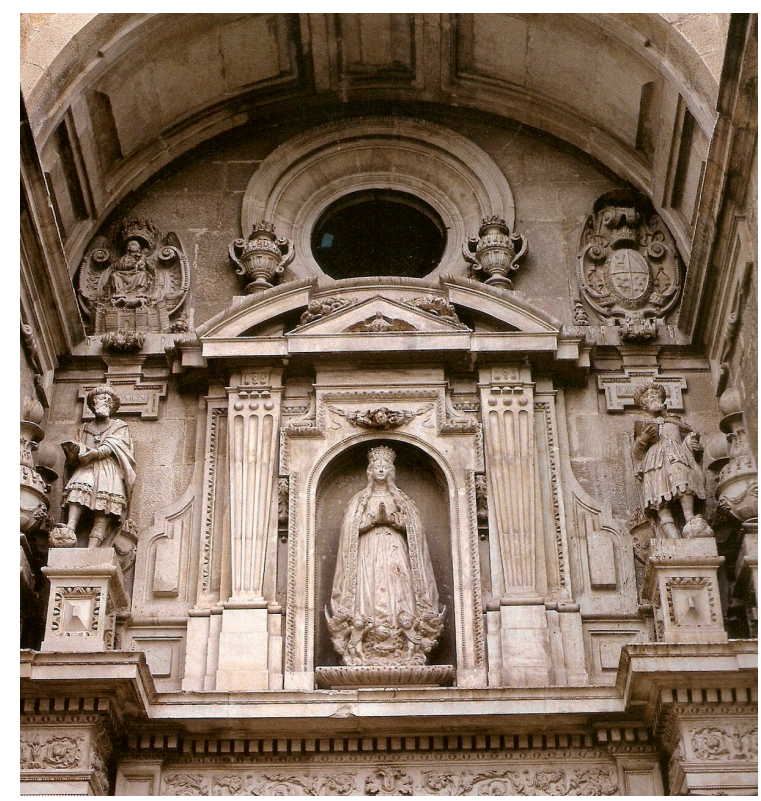

Fig. 4. Portada septentrional del crucero (1641).

31 La portada es diseño de Juan de Aranda (1641). Según Pedro Galera, "demuestra tanto su gusto y concepto artístico como el del gusto oficial de la Iglesia representada en la figura de don Baltasar de Moscoso, vid. GALERA, Pedro: La Catedral de Jaén... op. cit. p., 90.

32 CARAMUEL DE LOBKOWITZ, Juan: Architectura civil recta y obliqua, Vigevano, Camilo Corrado, 1678, proemial, III, 20, cfr. PENA BUJÁN, Carlos: "Las murallas del paraíso: Juan Caramuel y la arquitectura militar" en Mirando a Clio. El arte español reflejo de su historia. XVIII. Congreso CEHA, Santiago de Compostela 20-24 septiembre, 2010. Ma Dolores Barral, Enrique Fernández, Begoña Fernández, J. Manuel Monterroso (coords.). Universidad de Santiago de Compostela, Servicio de Publicaciones, 2012.

33 CARAMUEL DE LOBKOWITZ, Juan: op. cit., proemial, III, 20, cfr. PENA BUJÁN, C.: "Las murallas del paraíso..." op. cit. 


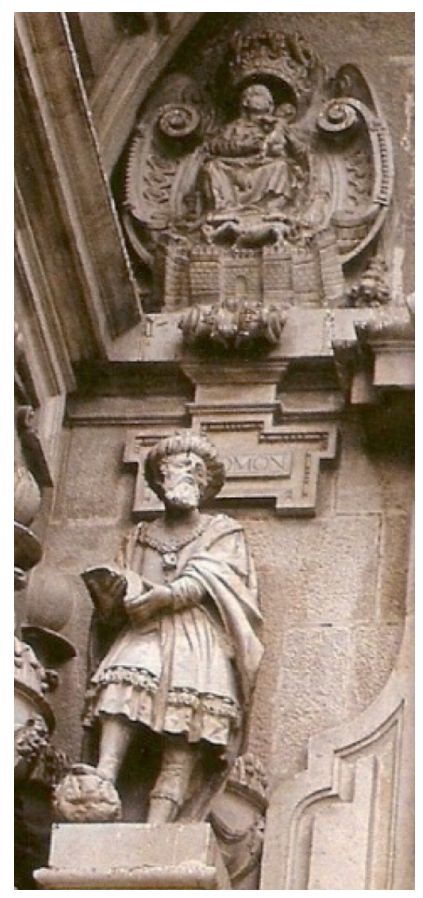

Fig. 4.1.

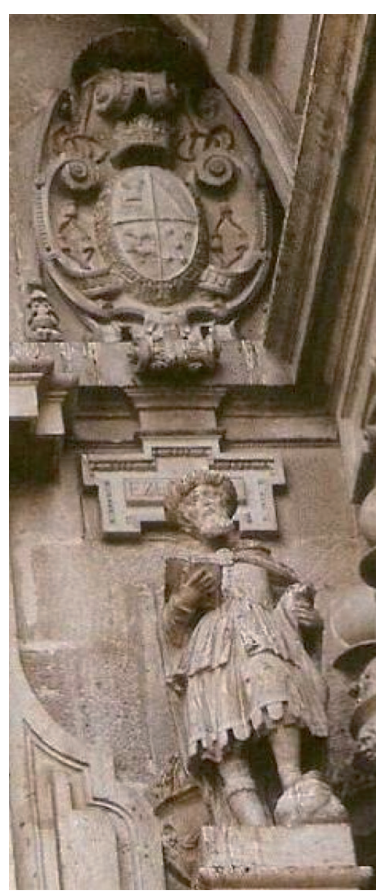

Fig. 4.2.

El antecedente más claro de la correspondencia Dios-arquitecto en la arquitectura española era El Escorial, cuya arquitectura literaria abunda en el parangón entre el monasterio y el Templo de Salomón, y en el consecuente paralelismo entre Felipe II y el sabio rey. ${ }^{34}$ La Catedral de Jaén es implícitamente equiparada, a partir de la analogía establecida por Núñez Sotomayor, con la que fue celebrada como octava maravilla del mundo, el monasterio escurialense. La categoría de prodigio arquitectónico adquirido por El Escorial arraigó con rapidez en el imaginario español y fue favorecida tanto por la propaganda visual del edificio, a través sobre todo de las estampas, como fundamentalmente por toda la literatura artística que lo relacionaba directamente con el Templo de Salomón. ${ }^{35}$ La comparación entre la Catedral de Jaén

34 Aunque el repertorio es amplio, la primera vez que se dice explícitamente que el Escorial es un nuevo Templo de Salomón es en la primera crónica del monasterio, escrita por fray Juan de la Cruz en 1591, sus palabras al respecto son: “... en este sancto templo, que con toda afición y deuocion mostrara y empleara en el sus riquezas el Catholico rey don Philipo, ofreciéndolo como otro Salomón”, cfr. PENA BUJÁN, Carlos: "La arquitectura de los bárbaros: Juan Caramuel de Lobkowitz y el “orden gótico", Quintana n 4 (2005), p. 211, n. 18.

35 Vid. PENA PUJÁN, Carlos: “¿Diseñó Dios el Escorial?: Caramuel, el salomonismo y la Octava Maravilla”, Studi Secenteschi, 46 (2005), pp. 259-280. La cita más antigua en la que se considera la octava maravilla se encuentra en las célebres octavas escritas en la Universidad de Alcalá de Henares en el año 1580 : “... el gran coloso de Rodas, sombra vana,/ ya con tal maravilla todas callan,/ porque estas siete y más aqui se hallan". Diez años más tarde Góngora compuso el soneto titulado "De San Lorenzo el Real del Escorial": "Sacros altos, dorados capiteles/ que a las nubes borráis sus arreboles,/ Febo os teme por más lucientes 
y El Escorial se hará, no obstante, explícita, siglos más tarde, cuando la retórica y la imaginería barroca reaparezcan a comienzos del siglo XIX:

¿Y quién el aparato suntuoso/ describir ahora puede/ de un Templo tan grandioso/ que es prodigio del arte/ su arquitectura bella,/ pudiéndose afirmar, que si no excedel a la del Escorial, en mucha parte/ no es inferior a ella:/ el concurso brillante, y numeroso/ que ocupa su anchuroso/crucero, y aun no cava[sic]/ en una y otra nave? ${ }^{36}$

\section{La supremacía de la arquitectura desde la mirada ilustrada}

Pero todavía en el siglo XVIII hay que reparar en una de las miradas más sutiles hacia el Templo Mayor. El espíritu de la Ilustración que condujo al Deán Martínez de Mazas a emprender la difícil tarea de redactar una historia de la ciudad de Jaén, dio finalmente como resultado -debido, como el propio Deán manifiesta, a la falta de documentación y de tradición historiográfica sobre la ciudad-, una amplia descripción de lo que la ciudad ofrecía ante sus ojos. En su Retrato al natural, ${ }^{37}$ fiel al espíritu neoclásico, valora la unidad estilística de la Catedral, fundada en el lenguaje clasicista, al considerar que su magnificencia y perfección se deben al "buen gusto del tiempo de Carlos V y Felipe II y al de la restauración de las Nobles Artes". ${ }^{38}$ No obstante, reconoce Martínez de Mazas su desconocimiento en materia de arquitectura, y antes de relatar las medidas precisas de cada una de las partes del edificio, aflora la mirada del espectador seducido por la magia del conjunto:

Quando me veo dentro de este magnifico Templo, y dirijo la vista hacia sus arcos, $y$ bóvedas sobre el ayre, me pasmo y me admiro de ver el sosiego con que están debajo tantas gentes, teniendo millones de arrobas de peso sobre sus cabezas. ;Qué arte será este que asi enseña a voltear sobre unas Columnas delgadas tantos ramos de piedra de mil piezas y labores, sin que alguna se disloque... ${ }^{39}$

Es esa ocasión, el Deán dirigía su mirada hacia lo alto, valorando la excelencia constructiva de la obra. Sin embargo, más interesantes resultan sus palabras cuando

soles/y el cielo por gigantes más crueles/...Perdone el tiempo, lisonjee la Parca/ la beldad de esta Octava Maravilla/ los años deste Salomón Segundo".

36 COELLO, Diego Antonio: Canto épico. El triunfo de la gracia en la conversión de Zabdia Bensabé, mora la mas obstinada en la creencia de su falsa ley: catequizada y bautizada solumnemente en la Santa Iglesia Catedral de Jaén en 23 de Marzo de 1817, por el Illmo. Señor Don Andrés Esteban y Gómez, Dignísimo Obispo de esta Diócesis (Jaén, Manuel María de Doblas, 1817), cfr. VALLADARES, Aurelio: "Testimonios literarios..." op. cit. p. 143.

37 MARTÍNEZ DE MAZAS, José: Retrato al natural de la ciudad y término de Jaén: su estado antiguo y moderno con demostración de cuanto necesita mejorarse su población, agricultura y comercio. Jaén, Imprenta de Don Pedro de Doblas, 1794. (ed. Facsímil, El Arbir, Barcelona, 1978), vid., AVILÉS FERNÁNDEZ, Miguel: "Jaén en el siglo XVIII visto por el clérigo ilustrado D. José Martínez de Mazas". Espacio, Tiempo y Forma, Serie IV, $H^{a}$ Moderna, t. 2 (1989), pp. 219-242.

38 MARTÍNEZ DE MAZAS, José: Retrato al natural..., op. cit. Capítulo VIII. Del Magnífico Templo de la Catedral de Jaén, p. 169.

39 Ibidem, pp. 203-204. 
la estimación del conjunto corresponde a la visión inversa, esto es, a la imagen que ofrece el Templo contemplado desde las alturas [fig. 5], un privilegio, sin duda, sólo al alcance de autoridades o dignidades como la que él mismo representaba:

El que ha de gozar de toda su hermosura es preciso que la mire desde las ventanas y balcones que la rodean por encima de las Capillas. Entonces se sorprenderá seguramente, y podrá decir: ;Terribilis est locus iste! Vere non est hic aliud nisi Domus Dei, et porta Coeli. Verá la correspondencia de todas sus partes, sin que haya una que desdiga de la otra ni en columnas, ni en capillas, ni en ventanas, vidrieras \& c. y todo elevado y grandioso. Verá la armonía y efecto que causa la gran solería de marmoles blancos y negros que adornan el pavimento... ${ }^{40}$

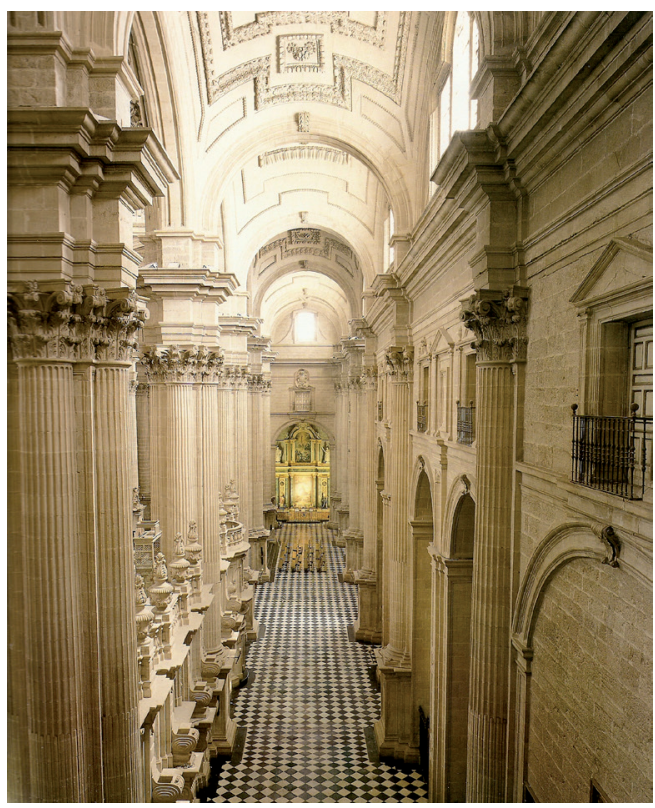

Fig. 5. Vista de la nave lateral derecha desde las galerías altas.

La singularidad de esta catedral constituía en definitiva, según el Deán, argumento suficiente para justificar la supremacía de la arquitectura sobre las demás artes. De este modo, el templo giennense sirve de colofón a un breve discurso en torno al paragone en donde se destacan algunas aportaciones de la arquitectura a la humanidad, entre otras, nos indica Mazas: "Nos puso en el Mar edificios flotantes", una alusión al arca de Noé, la primera obra del gran arquitecto del universo, que a la vez constituye una singular y visionaria metáfora con la que se anticipa en más de un siglo a uno de los símbolos de la arquitectura contemporánea: la metáfora del barco. ${ }^{41}$

\footnotetext{
40 Ibidem, pp. 215-216.

41 "La necesidad, y la naturaleza fueron los primeros inventores de las Artes. Despues el ingenio del hombre las dio su perfeccion, añadiendo a lo necesario lo útil, lo bello, y agradable. Asi se perfeccionaron entre los Griegos la Pintura, la Escultura y la Arquitectura: pero no sé por que manía se suele dar la preferencia á las
} 


\section{Imágenes de la Catedral en la Edad Contemporánea: baluarte de la Fe y joya divina}

La imagen de la Catedral de Jaén como baluarte de la Fe retorna en la segunda mitad del ochocientos. La fortaleza de sus torres se exalta en el romance ${ }^{\circ} \mathrm{XX}$ de Ciriaco Sidrach de Cardona, titulado "La Catedral", donde se destaca el aspecto elevado y sólido del edificio por medio de la evocación sonora de un huracán:

“-¿Qué haces aquí, Catedral/ limite dando a esa plazal donde te azota el furioso/ huracán de la montaña,/ que batir quiere las torres/ que te coronan gallardas?"/ Y el eco del viento dice/ bajando por la cañada....- "Esa es la fe de seis siglos/ que al espacio se levanta..." ${ }^{\prime 2}$

La esbeltez y firmeza de las torres de la catedral generó sutiles metáforas también a lo largo del siglo XX, tal y como se desprende de unos versos compuestos por Manuel Jurado López, pertenecientes a un poemario dedicado a Machado que lleva por subtítulo "Tarde de lluvia ante la catedral de Jaén": Llueve sobre la catedral/y sus gemelos mástiles de piedra... ${ }^{43}$

En 1867, el célebre poeta local Bernardo López García, publica un singular poema "polifónico" protagonizado por los personajes del Arte y la Fe en diálogo con la Duda. El poema titulado "La Catedral de Jaén" ${ }^{4}$ es, por una parte, heredero de géneros alegóricos como las loas y autos sacramentales, pero al mismo tiempo supone una descripción de la erección del Templo. ${ }^{45}$ El diálogo sostenido entre las tres alegorías concluye con una reafirmación de la $\mathrm{Fe}$ que, en correspondencia con el Arte, y entendido este como emanación del Creador, sellan su triunfo con un abrazo final sobre el monte donde se va a levantar el templo. Así comienza el poema:

Sobre un monte a cuyo pie/ duerme una ciudad sombría,/juntos se vieron un día/ La Duda, el Arte y la Fe...

dos primeras... Al contrario sucede con la Arquitectura que nos proporciona mil comodidades. Ella es la mas antigua, mas útil y necesaria para el hombre... Nos edificó las grandes Ciudades del Mundo... Nos puso en el Mar edificios flotantes... En fin la Arquitectura nos trazó, y dio el ser á esta magnifica obra de la Catedral...", Ibidem, pp. 205-206.

42 El Romancero de Jaén (Jaén, Imp. De Francisco López Vizcaíno, 1862).

43 Cfr. VALLADARES, Aurelio: “Testimonios literarios..." op. cit., p. 150.

44 LÓPEZ GARCÍA, Bernardo: Poesías (1867). Jaén. Tipografías de la regeneración, 1908 (3º edición). Un análisis del poema, así como una actualización de la biografía y obra de Bernardo López García en, JIMÉNEZ FERNÁNDEZ, Juan: "Jaén en la poesía de Bernardo López". Boletín del Instituto de Estudios Giennenses $n^{\circ} 139$, (1989), pp. 9-40. Del mismo autor véase, Bernardo López y su obra poética. Jaén, Instituto de Estudios Giennenses, 1988. SANCHO SÁEZ, Alfonso y SANCHO RODRÍGUEZ, Ma Isabel: Poesía giennense del siglo XIX. Jaén Diputación Provincial, 1991.

45 Según J. Jiménez Fernández, "la obra es perfecta, en el sentido de que es obra hecha, terminada, y hay que incluirla en el género alegórico calderoniano, del que ya Bernardo López dejó como muestra El arte y el siglo, loa apenas conocida, precisamente compuesta "para conmemorar el natalicio de Don Pedro Calderón de la Barca", cfr. JIMÉNEZ FERNÁNDEZ, Juan: op. cit. p. 28. 
Tras la presentación de los personajes, cada uno con sus atributos y símbolos, se exponen los motivos de la erección del templo, indicándose el emplazamiento dentro de la primitiva muralla que rodeaba la ciudad:

- ¿Y adónde vosotras dos/vais en tan dulce corrida?/-Hacia esa vega florida/ a elevar un templo a Dios./ Desde ese plácido edén/ que forman bosques oscuros,/ por en medio de esos muros/ en que se asienta Jaén,...

Tras los discursos de la $\mathrm{Fe}$ y el Arte termina la alegoría y comienza la descripción del templo, unos versos en los que se insiste en la grandiosidad del edificio ("muro colosal", "mole"), se repara en elementos arquitectónicos (columnas, capiteles, arcos), para constatar el fin último de la construcción, esto es, el Templo al servicio de la Fe:

...Crece el muro colosal; / la nave se alza y alienta;/ fuerte la columna asienta/ su mole en el pedestal, / y al beso de los cinceles/ que ornan el santo recinto/ brotan flores de Corinto/de los altos capiteles./Sobre base soberana/ el arco vibra y cimbrea:/ piedra a piedra va la idea/ recibiendo forma humana./Y el artista alzando el vuelo/fija la fe en su estandarte/ con flores que coge el arte,/ teje coronas al cielo...

Nuevamente, la armonía del conjunto va a ser resaltada por el poeta:

Detalles grandes y leves/ forman concierto sonoro;/ ya brotan formando coro/ flores, frisos y relieves;/ ya en las columnas más puras/ los nobles arcos se aferran;/ ya las bóvedas se cierran/ sobre las naves seguras;...

Y para alabar la belleza de la cúpula emplea una preciosa metáfora que remite a la Virgen, a quién está dedicada el Templo:

...y el genio del arte en pos/da a la cúpula su brillo/dejándola como anillo/de aquella esposa de Dios.

Una exquisita alegoría que se repite a lo largo del siglo XX, y con la que se corona la imagen de la catedral de Jaén como obra divina, es aquella en la que se la equipara a una joya:

La excelsa majestad de lo cristiano/ brilla en su mole, cual la luz sagrada,/ espléndida creación, joya labrada, / por el cincel del genio soberano. ${ }^{46}$

Relacionada con esta imagen está la que unos años después, en 1928, Rafael Láinez, catedrático de Arte en la universidad salmantina y también poeta, ofrece en el artículo "Nuevas rutas de la vieja España. Estampas líricas para un itinerario romántico", donde la catedral es descrita como un relicario de la Santa Faz:

46 RAMOS LUQUE, Miguel: "La Catedral” publicado en el diario ubetense La Provincia (15-9-1924), p. 1, cfr. VALLADARES, Aurelio: “Testimonios literarios...” op. cit. p. 146. 
“...frente al palacio de los obispos de Jaén, veréis erguirse con orgullo de hoguera encendida por la fe de todo un pueblo esa custodia gigante de la catedral... La catedral, la ciudad toda, con su historia pasada y con su vivir de hoy, no es más que el gran relicario guardador de la Cara Divina."

Esta metáfora materializa la imagen de la catedral como espacio concebido para acoger la reliquia del Santo Rostro, una veneración ampliamente desarrollada por las narraciones históricas en torno al episcopado y origen de la ciudad de Jaén. ${ }^{47} \mathrm{La}$ imagen de la catedral-relicario constituye, por otro lado, una utopía literaria emparentada con aquellas fantasías arquitectónicas que llegaron a ser materializadas "a escala" en custodias, relicarios, arquetas, cofres, etc., piezas que significaron durante siglos, en muchos casos, la aspiración de plasmar la utopía de "la gran obra" en oro, plata y piedras preciosas. ${ }^{48}$

El atributo de joya contribuye a reforzar la imagen del templo mayor giennense como espacio mítico de la ciudad, pieza preciosa que se yergue al margen del paso del tiempo. Así la considera Juan Eslava Galán al inicio y cierre de su novela Catedral:

ARCA DORADA/ diapasón del mundo/ caja de resonancia del más delicado instrumento/ Armónica Montaña...

Caja de resonancia del más delicado instrumento/ diapasón del mundo/ Arca Dorada./ CATEDRAL. ${ }^{49}$

De nuevo, como excelsa custodia la presentaba en el 2003 el poeta marteño Miguel Calvo Morillo en el soneto "La Catedral":

"Y el oro fue cegando mi mirada/ al contemplar tu nítida hermosura/ de piedra vertical, y tu locura/ de ganar el paraíso iluminada/ por los rayos del sol. Y aurificada/ ser custodia gigante y arboladura/ de un navio de recta singladura..." 50

El brillo de la luz en el interior del Templo guarda relación con la metáfora cristalina en algunos versos que, todavía a finales del siglo XX, describen la Catedral de Jaén. Ambas cualidades se relacionaban en la cosmovisión barroca con la Jerusalén celeste, tal y como viene descrita en el Apocalipsis, como ciudad hecha de cristal y piedras preciosas. Pero, de algún modo, al igual que en la bíblica ciudad, en la que no había necesidad de luz porque ya estaba iluminada con una luz que procedía de su interior, de

47 Los relatos en torno a la veneración del Santo Rostro se remontan a la Crónica del Condestable Miguel Lucas de Iranzo, donde se contienen varias alusiones a la reliquia de la Verónica. Estas y otras referencias en VALLADARES, Aurelio: op. cit, pp. 138-139.

48 Véase RAMÍREZ, Juan Antonio: "El templo utópico de oro y plata: custodia procesional de la catedral de Toledo por Enrique de Arfe (1515-1524)" en Edificios y sueños (Ensayos sobre Arquitectura y Utopía). Málaga, Universidad, 1983, pp. 29-33.

49 ESLAVA GALÁN, Juan: Catedral. Barcelona, Planeta, 1992. Con anterioridad el mismo autor en el soneto "Ella en la catedral", fechado en 1986, ya había tratado a la catedral como joya arquitectónica, cfr. VALLADARES, Aurelio, op. cit. p. 152-153.

50 CALVO MORRILLO, Miguel: "La Catedral", Claustro poético no 14, 2003, p. 25, cfr. VALLADARES, Aurelio, op. cit., p. 152. 
Cristo, los extraordinarios versos de Felipe Molina Verdejo realzan el aspecto cristalino de la Iglesia Mayor giennense, y desde una estética más fundada en lo formal, describe una catedral de cristal, una las grandes utopías de la arquitectura contemporánea: ${ }^{51}$

Piedras blancas, sagradas, / materia apenas; /luz, luz aprehendida,/ que se elevan, aladas, / toda gravitación ya suspendida .../ Polígonos del aire, geometría/ de la luz, concreciones/de espacio, de equilibrios, de armonía. ${ }^{52}$

Por último, no podemos dejar de incluir el breve pero elocuente testimonio escrito por Federico García Lorca y unos amigos en una postal fechada en Granada el 7 de noviembre de 1925, en el que supuso su segundo viaje a Jaén. En esta descripción late de modo sucinto algunas de las imágenes centenarias de la Catedral, la esbeltez, la luminosidad, la catedral-relicario:

“...la belleza de Jaén, con su catedral airosa, abierta por cientos de balcones a las calles y a la plaza, coronada de apóstoles y profetas y guardadora del Santo Rostro, que solemnisimamente adoramos. Se puede hacer el viaje por besar el cristal donde surge la cara bizantina de Cristo, aceitosa y llena de dulce intimidad entre las viejas esmeraldas y rubies del católico y viejo marco. Envuelta, además, en la unción sedosa de la liturgia..." ${ }^{53}$

Para finalizar, deseo cerrar el recorrido por las imágenes de la Catedral de Jaén en los últimos 350 años citando de nuevo a Chueca Goitia, con quien iniciaba esta senda, reproduciendo ahora unos versos en los que un anciano historiador del arte y arquitecto de noventa y dos años dejaba fluir abiertamente sus sentimientos hacia la ciudad de Jaén y su monumento más insigne, la Catedral:

Mira Inés, la Catedral/mírala bien y despacio/ cómo domina el espacio/ como centro espiritual./ Todo a su lado es pequeño/ en derredor por igual/ y no nos parece mal/ que lograran tal empeño./Vandelvira la inició,/ con sumo aliento divino/ y la siguieron con tino/ hasta quien la culminó./Las catedrales son muchas/ que a sus ciudades responden,/ algunas se nos esconden/ mas sus campanas escuchas./ Esto en Jaén no sucede,/ a su catedral rendida/ la ciudad estremecida/ sin duda alcanzar no puede/... ${ }^{54}$

51 Véase al respecto, MARCHÁN FIZ, Simón: "La corona de la ciudad: catedrales, "Casas del Pueblo" y rascacielos cristalinos" en La metáfora del cristal en las artes y en la arquitectura. Madrid, Siruela, 2008.

52 MOLINA VERDEJO, F.: "Catedral luminosa, la Catedral de Jaén” en Épico Jaén, lírico Jaén (Rapsodia en Morado). Ayuntamiento de Jaén, 1995, cfr. VALLADARES, Aurelio, op. cit., p. 149.

53 Cfr. CHICA, Francisco: "Jaén en Federico García Lorca". Boletín del Instituto de Estudios Giennenses $\mathrm{n}^{\mathrm{o}} 146,(1992)$, pp. 13-20.

54 CHUECA GOITIA, Fernando: “Alegoría de Jaén". Boletín del Instituto de Estudios Giennenses n 185 (2003), pp. 95-98. 